\title{
LETTERS
}

\section{Whom should we really call a "doctor"?}

This is in response to the News article by Roger Collier. ${ }^{1}$ These days many health professionals use the title "doctor." Indeed, The Canadian Press Stylebook now decrees that the title of doctor should be reserved for physicians. Physicians, surgeons, dentists, chiropodists, university professors and, in some countries, pharmacists describe themselves as doctors. This raises the question - are they? To answer this question, one has to examine that title from both linguistic and historical standpoints.

The word doctor is derived from the Latin verb "docere," meaning to teach, or a scholar. Only by special arrangement do any of the preceding professionals teach. Only university professors with a doctoral degree normally teach at a university. Historically speaking, the title doctor was invented in the Middle Ages to describe eminent scholars. These doctorates date back to the 1300 s. Such people were accorded a lot of respect and prestige.

The PhD, or Doctor of Philosophy, is the highest graduate degree awarded by our universities.
Health professionals receive undergraduate degrees in medicine. These are professional degrees, and not really doctorates. The MD degree is not a part of graduate faculties at North American universities.

It has now become fashionable to award so-called Doctor of Law degrees to undergraduate law school graduates in the form of a Juris Doctor or JD degree, including at the University of Windsor. These, too, are merely undergraduate degrees.

Because of the respect and prestige, medical schools, particularly in Scotland, started to address their graduates as doctors in the 17th century. The argument was that graduates of such schools obtain a bachelor's degree before joining medical school. There are problems with such logic, namely, a degree past a bachelor's degree could potentially be a master's degree, but not a doctoral degree.

A doctoral degree (PhD) is a degree that one earns after a master's degree. A PhD entitles a person to use the title doctor. These are the social and physical scientists who conduct and evaluate published research. A PhD degree is normally obtained after six to eight years of hard work past the bachelor's degree.
When we are asked in a physician's or a dentist's office what kind of doctor we are, we respond, "the real one." We are the ones who teach the others.

We hope that this contribution helps in clearing up the confusion in the community about the title doctor.

The Canadian Press should change its policy and stylebook to reflect these facts and this history.

This contribution should not be construed as an attack on any professional or group of professionals. The main purpose here is to educate the public.

\section{Abdul-Fattah A. Asfour PhD}

Professor, Environmental Engineering, Faculty of Engineering, University of Windsor, Windsor, Ont.

James P. Winter PhD

Professor, Graduate Program in

Communication and Social Justice, University of Windsor, Windsor, Ont.

Cite as: CMAJ 2018 May 28;190:E660. doi: $10.1503 / \mathrm{cmaj} .69212$

\section{Reference}

1. Collier R. Who is entitled to the title of "doctor"? CMAJ 2016;188:E305.

Competing interests: None declared. 